\title{
Protein Kinase $C \delta$ Mediates Cerebral Reperfusion Injury In Vivo
}

\author{
Rachel Bright, ${ }^{1}$ Ami P. Raval, ${ }^{5}$ Jeffrey M. Dembner, ${ }^{2}$ Miguel A. Pérez-Pinzón, ${ }^{5}$ Gary K. Steinberg, ${ }^{2,3,4}$ \\ Midori A. Yenari, ${ }^{2,3,4}$ and Daria Mochly-Rosen ${ }^{1}$ \\ Departments of ${ }^{1}$ Molecular Pharmacology, ${ }^{2}$ Neurosurgery, and ${ }^{3}$ Neurology and Neurological Sciences, ${ }^{4}$ Stanford Stroke Center, Stanford University School \\ of Medicine, Stanford, California 94305, and ${ }^{5}$ Cerebral Vascular Disease Research Center, Department of Neurology and Neuroscience, University of Miami \\ School of Medicine, Miami, Florida 33101
}

Protein kinase $\mathrm{C}(\mathrm{PKC})$ has been implicated in mediating ischemic and reperfusion damage in multiple organs. However, conflicting reports exist on the role of individual PKC isozymes in cerebral ischemic injury. Using a peptide inhibitor selective for $\delta \mathrm{PKC}, \delta \mathrm{V} 1-1$, we found that $\delta \mathrm{PKC}$ inhibition reduced cellular injury in a rat hippocampal slice model of cerebral ischemia [oxygen-glucose deprivation (OGD)] when present both during OGD and for the first $3 \mathrm{hr}$ of reperfusion. We next demonstrated peptide delivery to the brain parenchyma after in vivo delivery by detecting biotin-conjugated $\delta \mathrm{V} 1-1$ and by measuring inhibition of intracellular $\delta \mathrm{PKC}$ translocation, an indicator of $\delta \mathrm{PKC}$ activity. Delivery of $\delta \mathrm{V} 1-1$ decreased infarct size in an in vivo rat stroke model of transient middle cerebral artery occlusion. Importantly, $\delta \mathrm{V} 1-1$ had no effect when delivered immediately before ischemia. However, delivery at the onset, at $1 \mathrm{hr}$, or at 6 $\mathrm{hr}$ of reperfusion reduced injury by 68,47 , and $58 \%$, respectively. Previous work has implicated $\delta$ PKC in mediating apoptotic processes. We therefore determined whether $\delta \mathrm{PKC}$ inhibition altered apoptotic cell death or cell survival pathways in our models. We found that $\delta$ V1-1 reduced numbers of terminal deoxynucleotidyl transferase-mediated biotinylated UTP nick end labeling-positive cells, indicating decreased apoptosis, increased levels of phospho-Akt, a kinase involved in cell survival pathways, and inhibited BAD (Bcl-2-associated death protein) protein translocation from the cell cytosol to the membrane, indicating inhibition of proapoptotic signaling. These data support a deleterious role for $\delta \mathrm{PKC}$ during reperfusion and suggest that $\delta \mathrm{V} 1-1$ delivery, even hours after commencement of reperfusion, may provide a therapeutic advantage after cerebral ischemia.

Key words: ischemia; OGD; neuroprotection; hippocampus; peptide inhibitor; PKC

\section{Introduction}

Stroke is a leading cause of disability and death worldwide (National Institute of Neurological Disorders and Stroke, 1995). Both ischemia and the restoration of blood flow to ischemic tissue (reperfusion) cause cellular damage, possibly by different molecular mechanisms (Chan, 2001). Protein kinase C (PKC) has been implicated in mediating ischemic and reperfusion insults in multiple organs (Downey et al., 1994; Padanilam, 2001). However, much of this work has focused on the role of PKC in cardiac protection. Ischemic episodes to the brain also result in activation of several PKC isozymes (Wieloch et al., 1991; Sieber et al., 1998; Selvatici et al., 2003). However, there is no consensus on

Received June 27, 2003; revised June 19, 2004; accepted June 19, 2004.

This work was supported by National Institutes of Health (NIH) Research Grants NS40516 (M.A.Y.), P01 NS37520 and R01 NS27292 (G.K.S.), NS44350 (D.M.-R.), and NS34773 (M.A.P.-P.) and by State of California Funds for medical research on alcohol and substances of abuse (D.M.-R.), American Heart Association Grant 0225227B, a FloridaPuerto Rico affiliates postdoctoral fellowship (A.P.R.), and NIH-National Institute of Neurological Disorders and Stroke Predoctoral Fellowship NS45413-01 (R.B.). We gratefully acknowledge the assistance of Beth Hoyte for figure preparation. D.M.-R. is a founder of KAI Pharmaceuticals, whose goal is to bring peptide regulators of protein kinase C to the clinic. However, the research described in this study was performed in her laboratory at the university and with sole support from the NIH and State of California Funds to her university activities.

Correspondence should be addressed to Daria Mochly-Rosen, Department of Molecular Pharmacology, Stanford University School of Medicine, Stanford, CA 94305-5174. E-mail: mochly@stanford.edu.

D01:10.1523/JNEUROSCI.4474-03.2004

Copyright $\odot 2004$ Society for Neuroscience $\quad$ 0270-6474/04/246880-09\$15.00/0 which isozymes are involved in mediating the cellular response or whether PKC activation is damaging or beneficial.

Recent reports have linked PKCs to modulation of several signaling pathways, including mediation of excitatory or inhibitory amino acid release (Nakane et al., 1998) and cytokineinduced superoxide production (Chao et al., 1995). In addition, a growing body of literature suggests that the $\delta \mathrm{PKC}$ isozyme is involved in apoptotic pathways, including mediating caspase activation and regulation of mitochondrial function (Brodie and Blumberg, 2003). This mode of cell death is observed during delayed cerebral reperfusion injury and contributes to the overall damage seen after stroke (for review, see Lipton, 1999). Importantly, $\delta \mathrm{PKC} \mathrm{mRNA}$ and protein levels are increased in the cortex and hippocampus after global ischemia and in the compromised peri-infarct region after focal cerebral ischemia (Miettinen et al., 1996; Koponen et al., 2000). This penumbral area, where increased $\delta$ PKC expression was noted, is prone to delayed damage (Phan et al., 2002), suggesting a role for this isozyme in reperfusion injury.

The aim of this study was to determine the role of $\delta \mathrm{PKC}$ in cerebral ischemic-reperfusion injury. To establish whether changes in $\delta \mathrm{PKC}$ activity contribute to the outcome from cerebral ischemia, we used the $\delta \mathrm{PKC}$-selective inhibitor peptide $\delta$ V1-1 (Chen et al., 2001). This rationally designed peptide was 
found to selectively inhibit $\delta \mathrm{PKC}$ translocation and induce cardioprotection from ischemia-reperfusion in isolated cells (Chen et al., 2001) and in intact hearts ex vivo and in vivo (Chen et al., 2001; Inagaki et al., 2003a,b). Intracellular delivery of the $\delta \mathrm{V} 1-1$ peptide was enabled by cross-linking it via a cysteine S-S (Cys $\mathrm{S}-\mathrm{S}$ ) bond to a membrane-permeable carrier peptide (Tat) derived from the Tat human immunodeficiency virus (HIV) protein (Schwarze et al., 1999).

Here, we report that treatment with $\delta \mathrm{V} 1-1$ protected against cerebral ischemic-reperfusion damage in both the in vitro and in vivo models. Delivery of $\delta \mathrm{V} 1-1$ during reperfusion reduced apoptotic cell death and enhanced prosurvival signaling, suggesting that inhibition of $\delta \mathrm{PKC}$ during the reperfusion period reduces injury in part by blocking intrinsic cell death pathways that contribute to secondary damage. Therefore, $\delta \mathrm{PKC}$ mediates, at least in part, reperfusion-induced injury after stroke.

\section{Materials and Methods}

Peptide preparation. Tat carrier peptide and $\delta \mathrm{V} 1-1$ ( $\delta \mathrm{PKC}$ inhibitor peptide) were synthesized and conjugated via a Cys S-S bond as described previously (Chen et al., 2001). The $\delta$ V1-1-Tat-conjugated peptide is referred to as $\delta \mathrm{V} 1-1$. $\delta \mathrm{PKC}$ isozyme-specific activity of the $\delta \mathrm{V} 1-1$ peptide has been demonstrated previously (Chen et al., 2001; Inagaki et al., 2003a,b). An important difference between Tat fusion proteins (Asoh et al., 2002; Cao et al., 2002; Kilic et al., 2002) and the Tat peptide mentioned here is the use of a cysteine S-S bond, which links the peptide to the Tat. This is to allow the peptide to be trapped inside the cells, because it is cleaved and released from the Tat carrier after intracellular delivery by reduction of the S-S bond.

Preparation of cultures. Organotypic hippocampal slice cultures were prepared as described by Bergold and Casaccia-Bonnefil (1997). Briefly, Sprague Dawley neonatal rats (9-11 d of age) were anesthetized by intraperitoneal injections of ketamine (1.0 $\mathrm{mg}$ for each pup). Pups were decapitated, and the hippocampi were dissected and transversely sliced $(400 \mu \mathrm{m})$ on a McIlwain tissue chopper. Slices were placed in Gey's balanced salt solution (Invitrogen, San Diego, CA) supplemented with $6.5 \mathrm{mg} / \mathrm{ml}$ glucose (Sigma, St. Louis, MO) for $1 \mathrm{hr}$ at $4^{\circ} \mathrm{C}$. Slices were then transferred onto $30 \mathrm{~mm}$ diameter membrane inserts (Millicell-CM; Millipore, Bedford, MA) and placed into six-well culture trays with $1 \mathrm{ml}$ of slice culture medium per well. The slice culture medium consisted of 50\% Minimum Essential Medium, 25\% HBSS, and 25\% heat-inactivated horse serum (Invitrogen) supplemented with $6.5 \mathrm{mg} / \mathrm{ml}$ glucose and glutamine $(1 \mathrm{~mm})$. Cultures were maintained at $36^{\circ} \mathrm{C}$ in an incubator (100\% humidity; $5 \% \mathrm{CO}_{2}$ ) (CF autoflow; NuAire, Plymouth, $\mathrm{MN}$ ) and kept in culture for $14-15 \mathrm{~d}$ before experiments.

Animal protocols were approved by the Stanford University Institutional Animal Care and Use Committee and the University of Miami Animal Care and Use Committee.

Oxygen and glucose deprivation. To model ischemia, cultures were exposed to oxygen and glucose deprivation (OGD) using an anaerobic chamber. The slices were washed three times with glucose-free HBSS, $\mathrm{pH}$ 7.4, containing (in mM): $1.26 \mathrm{CaCl}_{2}, 5.37 \mathrm{KCl}, 0.44 \mathrm{KH}_{2} \mathrm{PO}_{4}, 0.49 \mathrm{MgCl}_{2}$, $0.41 \mathrm{MgSO}_{4}, 136.9 \mathrm{NaCl}, 4.17 \mathrm{NaHCO}_{3}, 0.34 \mathrm{Na}_{2} \mathrm{HPO}_{4}, 15$ sucrose (all from Sigma). The slices were then placed into an airtight chamber, and $95 \% \mathrm{~N}_{2} 5 \% \mathrm{CO}_{2}$ gas $\left(36^{\circ} \mathrm{C}\right)$ was circulated through the chamber for 5 $\min (4 \mathrm{~L} / \mathrm{min})$ to achieve anoxic conditions. After $5 \mathrm{~min}$, the chamber was sealed and placed in the incubator $\left(36^{\circ} \mathrm{C}\right.$ ) for $35 \mathrm{~min}$ (total of $40 \mathrm{~min}$ OGD). After OGD, the slices were placed back in the incubator in normal culture medium. Peptides Tat or $\delta \mathrm{V} 1-1$ were delivered in the culture medium at times stated. The organotypic slices were divided into groups (see Fig. 1): group 1, sham slices were incubated for 40 min with HBSS solution supplied with equimolar concentration of glucose instead of sucrose ( min of OGD $(n=15)$; group 3 , Tat plus ischemia Tat peptide during OGD alone $(n=5)$; group $4, \delta \mathrm{V} 1-1$ plus ischemia $\delta \mathrm{V} 1-1$ peptide during OGD alone $(n=6)$; group 5 , Tat during ischemia and reperfusion Tat during OGD and the first $3 \mathrm{hr}$ of reperfusion $(n=8)$; group $6, \delta \mathrm{V} 1-1$ during ischemia and reperfusion $\delta \mathrm{V} 1-1$ during OGD and the first $3 \mathrm{hr}$ of reperfusion ( $n=12$; all peptides $500 \mathrm{~nm}$ final concentration). For control, all six-well plates contained at least one well for sham and ischemia groups. Two hippocampal slices obtained from two different pups were placed on one insert. Therefore, the data obtained from each slice represents a different animal, and thus each slice is considered as $n=1$.

Assessment of cell death by image analysis using propidium iodide. Propidium iodide (PI; Sigma), a cell impermeable DNA dye, was used to identify dead cells. Before OGD, slices were incubated in medium supplemented with $2 \mu \mathrm{g} / \mathrm{ml}$ PI for $1 \mathrm{hr}$ and then replaced by regular media. Slices were studied using an inverted fluorescence microscope (Olympus IX 50; Olympus Optical, Tokyo, Japan), and pictures were taken using a SPOT CCD camera (Diagnostic Instruments, Sterling Heights, MI) and SPOT advanced software. Bright-field (0.254 sec exposure) and PI images (1.9 sec exposure; red filter) of slices were taken before the experiment. After imaging, the slices were exposed to OGD, and PI fluorescence images were taken $24 \mathrm{hr}$ later. To quantitate total cell death in all slices, an overdose of NMDA (100 $\mu \mathrm{M}$; Sigma) was applied to the culture medium. The last image was taken $24 \mathrm{hr}$ after $1 \mathrm{hr}$ NMDA treatment. Bright-field images were used to align the slice in the identical position during subsequent measurements. The intensity of PI fluorescence in the CA1 subfield of the hippocampal slices was used as an index of cell death.

For quantification purposes, fluorescence images were taken for each slice at $24 \mathrm{hr}$ after NMDA treatment, $24 \mathrm{hr}$ after OGD, and onset of experiment, and images were stacked using Scion Image software (Scion, Frederick, MD). The region of interest (ROI) was selected from the final image depicting total neuronal cell death, which remained constant for a particular slice. The ROI was subsequently superimposed on the fluorescence images taken $24 \mathrm{hr}$ after OGD and at the onset of the experiment. Relative cell death was calculated from each ROI as follows: relative percentage of cell death $=(F \exp -F \min ) /(F \max -F \min ) \times 100$, where Fexp is the fluorescence of the test condition, Fmax is maximum fluorescence (NMDA treatment), and Fmin is background fluorescence. For all experimental analyses, the results are expressed as mean \pm SEM. Statistical significance was determined with an ANOVA test followed by a Bonferroni's post hoc test.

Middle cerebral artery occlusion model. Ischemia was induced in male Sprague Dawley rats (290-320 gm) using an occluding intraluminal suture as described previously (Maier et al., 2001). Briefly, an uncoated 30 $\mathrm{mm}$ long segment of 3-0 nylon monofilament suture with the tip rounded by a flame was inserted into the stump of the external carotid artery and advanced into the internal carotid artery $\sim 19-20 \mathrm{~mm}$ from the bifurcation to occlude the ostium of the middle cerebral artery (MCA). At the end of the ischemic period ( $2 \mathrm{hr})$, the suture was removed and the animal was allowed to recover. Animals were maintained under isoflurane anesthesia during all surgical procedures. Tat or $\delta \mathrm{V} 1-1$ peptides were delivered as a bolus dose by intraluminal catheter directly into the internal carotid artery (pre- $\delta \mathrm{V} 1-1$ and post- $\delta \mathrm{V} 1-1$ groups; $0.06 \mathrm{mg} /$ $\mathrm{kg}$ ) or as an intraperitoneal dose (delayed- $\delta \mathrm{V} 1-1$ doses; 1 and $6 \mathrm{hr}$ postreperfusion; $0.2 \mathrm{mg} / \mathrm{kg}$ ). Physiological parameters including body temperature $\left(35-38^{\circ} \mathrm{C}\right)$ and respiration rate were monitored and maintained using a heat blanket and anesthetic adjustment. For PKC translocation assays, rats were killed at the end of the ischemic period (without removal of the suture) after a $10 \mathrm{~min}$ or $24 \mathrm{hr}$ reperfusion. The brain was sliced and striatum isolated and snap frozen.

Assessment of behavior after middle cerebral artery occlusion. Behavior was assessed at $24 \mathrm{hr}$ of reperfusion using a scale modified from the study by Yang et al. (1994). After $24 \mathrm{hr}$ of reperfusion, animals were graded on a scale of 1-4: grade 1, normal posture, spontaneous movement in any direction; grade 2, unilateral paw extension when lifted by the tail; grade 3 , both paw extension and circling pattern when spontaneously walking; grade 4, abnormal posture, paw extension, circling pattern, cannot walk spontaneously. Animals from one of the four treatment time point groups (delivery of $\delta \mathrm{V} 1-1$ or control peptides at $6 \mathrm{hr}$ reperfusion) were scored for behavior. Results were expressed as the mean \pm SEM behavior score. Statistical analyses were performed using ANOVA followed by Fisher's post hoc test.

Assessment of brain infarct size. Animals were killed after $24 \mathrm{hr}$ of reperfusion by an anesthetic overdose. Brains were quickly removed and sliced 
into $3 \mathrm{~mm}$ coronal sections, resulting in five slices of the brain. Slices were stained using 3\% triphenyl tetrazolium chloride (TTC), and both faces of each slice were photographed for infarct assessment. Relative stroke area (ratio of the infarct size relative to the ipsilateral hemisphere, corrected for edema on the basis of measurement of the contralateral hemisphere) was measured to assess infarct size in the central three slices (two faces each; six faces total) of the five slices made from each brain. Results were expressed as the mean \pm SEM infarct size of these six faces. All statistical analyses were performed using ANOVA followed by Bonferroni's post hoc test.

Measurement of apoptotic cell nuclei by terminal deoxynucleotidyl transferase-mediated biotinylated UTP nick end labeling staining. Terminal deoxynucleotidyl transferase-mediated biotinylated UTP nick end labeling (TUNEL) was performed both in the in vitro hippocampal slice model and the in vivo middle cerebral artery occlusion (MCAO) model. Briefly, hippocampal slices were subjected to OGD and treated with $\delta \mathrm{V} 1-1$ or control peptides as described above (groups 1, 5, and 6), followed by $24 \mathrm{hr}$ of reperfusion. Slices were stained using TUNEL with tetramethyl-rhodamine red label (Roche, Hertforshire, UK). Slices were viewed on a Carl Zeiss Laser Scanning Microscope (LSM) 510 (Zeiss, Thornwood, NY). The images of the sections were analyzed using LSM 5 image browser. In the in vivo model, animals underwent a $2 \mathrm{hr} \mathrm{MCAO}$ occlusion, and Tat or $\delta \mathrm{V} 1-1$ peptides were delivered as an intraarterial bolus dose at the onset of reperfusion as described above. Animals were killed after $72 \mathrm{hr}$ of reperfusion and transcardially perfused with normal saline followed by $4 \%$ paraformaldehyde. Brains were isolated and fixed overnight in $4 \%$ paraformaldehyde, immersed in $30 \%$ sucrose for 2-3 d, and snap frozen in OCT cryoprotectant (Tissue-Tek, Miles, Elkhart, IN). Three $16 \mu \mathrm{m}$ coronal slices were taken from equivalent midbrain regions in each brain, with each slice separated by at least $48 \mu \mathrm{m}$. Slides were stained after TUNEL kit protocol (Roche). Images were taken from four defined regions within the ipsilateral cortex of each slice. Cells were differentiated as being apoptotic both by positive staining and distinct morphology, including nuclear fragmentation suggestive of chromatin condensation; cells with diffuse, dim staining were not counted as apoptotic (Conti et al., 1998). Cell counts from the three slices taken from each brain were averaged to give a representative total number of cells within each image. An average cell count per brain was then calculated from each of the groups $(n=3-5$ per group). Results were expressed as the percentage of change in TUNEL-positive cell number with respect to control animals.

Western blot analysis. Brains were quickly isolated, sliced, and striatal regions dissected from each central slice and frozen. Tissue fractionation, both from whole organotypic slices and striatal region of isolated brains, was performed to collect soluble (cytosolic) and particulate (membrane) fractions as described previously (Johnson and Mochly-Rosen, 1995). Protein concentration was assessed using Bradford reagent, and $10 \mu \mathrm{g}$ of total lysate ( $40 \mu \mathrm{g}$ from hippocampal slice lysate) from each fraction was subjected to gel electrophoresis (10\% bis-acrylamide gel) and transferred to nitrocellulose membrane. Blots were blocked in 3\% milk TBST, probed with an anti-phospho-serine $643 \delta$ PKC antibody (1:500; Santa Cruz Biotechnology, Santa Cruz, CA) in 2\% BSA Tris-buffered saline Tween 20 (TBST) and probed with an anti-rabbit secondary (Amersham Biosciences, Arlington Heights, IL). Density of $\delta$ PKC bands was mea-
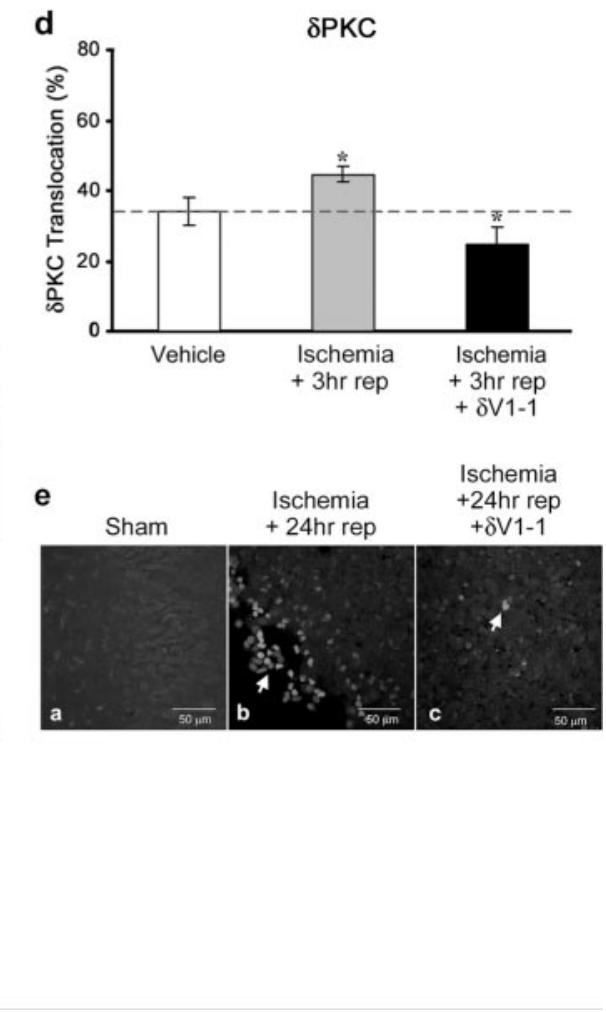

Figure 1. $\delta P K C$ inhibition reduces cellular death after OGD and reperfusion in hippocampal slices. $a$, Experimental protocol. $b$, Bright-field images (top) and corresponding PI fluorescence images (bottom) from hippocampal slice cultures of sham, ischemic, and $\delta V 1-1$-treated groups (left, middle, and right, respectively). Scale bar, $2.25 \mathrm{~mm}$. c, Quantitative measurements of PI staining peptide treatment ( $n=5$; group 3), or $\delta$ V1-1 peptide treatment ( $n=6$; group 4) during ischemia alone, Tat peptide treatment ; group 5) or $\delta V 1-1$ treatment ( $n=12$; group 6 ) during ischemia and for the first $3 \mathrm{hr}$ of reperfusion ( $3 \mathrm{hr}$ rep). Significant serfusion period inhibits $\delta$ PKC translocation in the in vitro slice model; $n=5$, all groups; ${ }^{*} p<0.05$ by Student's $t$ test. $e$, TUNEL UNEL-positive cells are found in the CA1 region of hippocampus from organotypic slice cultures (magnification, $40 \times$ ). Shamtreated slices contained few, if any, TUNEL-positive cells ( $a$ ). A larger number of TUNEL-positive cells (arrow) was observed $24 \mathrm{hr}$ after $40 \mathrm{~min}$ of $0 \mathrm{GD}(b)$. $\delta$ PKC inhibition reduced the TUNEL-positive cells $24 \mathrm{hr}$ after $40 \mathrm{~min}$ of $0 \mathrm{GD}(c)$.

sured to assess translocation of PKC from the cytosol to membrane fractions, a measure of activation (Kraft and Anderson, 1983). To assay Akt and BAD (Bcl-2-associated death protein) proteins, $20 \mu \mathrm{g}$ of brain lysate was run on 12.5 and $15 \%$ gels, respectively, blotted to nitrocellulose and blocked as described above, and probed with anti-phospho-Akt antibody (1:500; Biosource International, Camarillo, CA) or anti-BAD antibody (1:250; Santa Cruz Biotechnology) followed by anti-rabbit secondary. Blots were then stripped and reprobed with anti-Akt antibody (1:500; Cell Signaling Technology, Beverly, MA) or $\beta$-actin (1:5000; Sigma) to confirm equal protein loading. Densities were measured from Western blot autoradiograms. All statistical analyses were performed using ANOVA followed by Fisher's post hoc tests.

\section{Results}

$\delta \mathrm{PKC}$ inhibition reduces reperfusion injury in hippocampal slice model of oxygen and glucose deprivation

We first determined whether delivery of $\delta \mathrm{V} 1-1$, a peptide inhibitor of $\delta \mathrm{PKC}$, affected neuronal cell injury after OGD and reperfusion in an in vitro hippocampal slice model. This protocol leads to rapid death of CA1 pyramidal cells and granule cells, which manifests within $24 \mathrm{hr}$ of reperfusion (Bergold and CasacciaBonnefil, 1997; Pringle et al., 1997; Raval et al., 2003). Propidium iodide fluorescence was measured to assess cell death (Fig. 1b). In all experiments, OGD-induced cell damage is expressed as a frac- 
tion of total cell death when an overdose of NMDA $(100 \mu \mathrm{M})$ was applied to the culture medium. We found that $40 \mathrm{~min}$ of OGD followed by $24 \mathrm{hr}$ of reperfusion (oxygen and glucose are reapplied) led to $\sim 70 \%$ cell death in CA1 pyramidal cells compared with $4 \%$ death in slices maintained in normoxic conditions (Fig. $1 b, c$ ).

When slices were treated with the $\delta \mathrm{PKC}$-selective inhibitor $\delta \mathrm{V} 1-1(500 \mathrm{nM})$, during the ischemic period and during the first $3 \mathrm{hr}$ of reperfusion, the percentage of neuronal death decreased by $43 \%$, from $69 \pm 3 \%$ in control to $39 \pm 6 \%$ (Fig. $1 c$, group 6 ) $(p<0.05)$. However, treatment with $\delta \mathrm{V} 1-1$ during the ischemic period only did not confer any neuroprotection; $71 \pm 2 \%$ neuronal death was observed (Fig. 1c, group 4). Tat control was not protective when added at either time point (Fig. $1 c$, groups 3,5 ). These data demonstrate that the presence of the $\delta \mathrm{PKC}$ inhibitor during the ischemic period only conferred no protection. In contrast, inhibition of $\delta \mathrm{PKC}$ during the reperfusion period greatly reduced neuronal cell death in this in vitro model of ischemicreperfusion injury.

\section{$\delta$ V1-1 peptide inhibits $\delta \mathrm{PKC}$ translocation in vitro}

We next confirmed that $\delta \mathrm{V} 1-1$ peptide exerted its biological effect and inhibited $\delta$ PKC activity. Redistribution of PKC from the soluble to the particulate fraction (PKC translocation) is a marker for PKC activation (Kraft and Anderson, 1983) and has been used in numerous studies to assess enzyme activity (Wieloch et al., 1991; Selvatici et al., 2002). We therefore assessed $\delta$ PKC translocation in slices treated with the $\delta \mathrm{V} 1-1$ peptide for the first $3 \mathrm{hr}$ of reperfusion. We found a $24 \%$ increase in $\delta \mathrm{PKC}$ translocation in slices subjected to OGD followed by $3 \mathrm{hr}$ of reperfusion, indicating that $\delta \mathrm{PKC}$ was activated. In slices treated with $\delta \mathrm{V} 1-1$ peptide during ischemia and reperfusion, $\delta \mathrm{PKC}$ translocation was reduced by $45 \%$ (Fig. $1 d)(p<0.05)$.

\section{$\delta \mathrm{V} 1-1$ peptide reduces number of apoptotic cells after OGD in vitro}

To determine the mechanism by which $\delta \mathrm{V} 1-1$ confers neuroprotection, we assessed the number of cells undergoing apoptotic cell death after ischemic-reperfusion injury using TUNEL staining. In the hippocampal slice model, few, if any, TUNEL-positive cells were detected in sham-treated slices (Fig. 1ea). TUNEL-positive cells were abundantly detected in the CA1 region after $40 \mathrm{~min}$ OGD and $24 \mathrm{hr}$ of reperfusion in the Tat control peptide-treated group (Fig. 1eb). The number of TUNEL-positive cells was markedly diminished in slices treated with $\delta \mathrm{V} 1-1$ peptide (Fig. 1ec).

\section{$\delta \mathrm{V} 1-1$ peptide delivery to brain parenchyma}

To determine whether $\delta \mathrm{PKC}$ inhibition protects the brain from reperfusion damage after prolonged ischemia in vivo, we first demonstrated that $\delta \mathrm{V} 1-1$ conjugated to Tat can be delivered across the blood-brain barrier. Peptides cannot be readily delivered across the blood-brain barrier into the brain parenchyma. However, previous work by Schwarze et al. (1999) demonstrated that a Tat peptide, derived from the HIV Tat protein, crosses biological membranes and can serve as a carrier to other cargo, including proteins. An intra-arterial bolus of biotinylated $\delta \mathrm{V} 1-1$ was injected into the internal carotid artery $(2.5 \mu \mathrm{M}$ final blood concentration), and the brains were harvested after $30 \mathrm{~min}$. Using avidin-biotin complex, we detected the presence of the peptide in pyramidal cells in the cortex, suggesting effective delivery of the peptide into the brain parenchyma through the blood-brain barrier (Fig. 2a).

We next assessed the activity of $\delta \mathrm{PKC}$ in an in vivo transient a
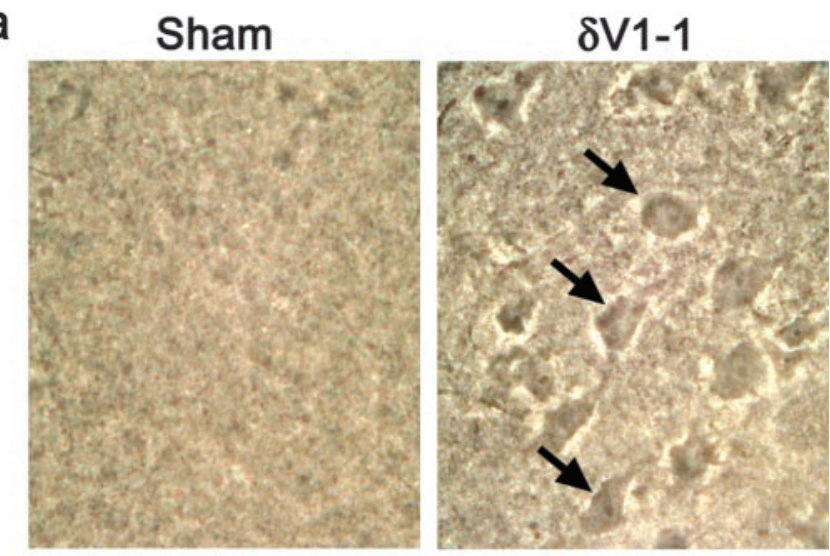

b
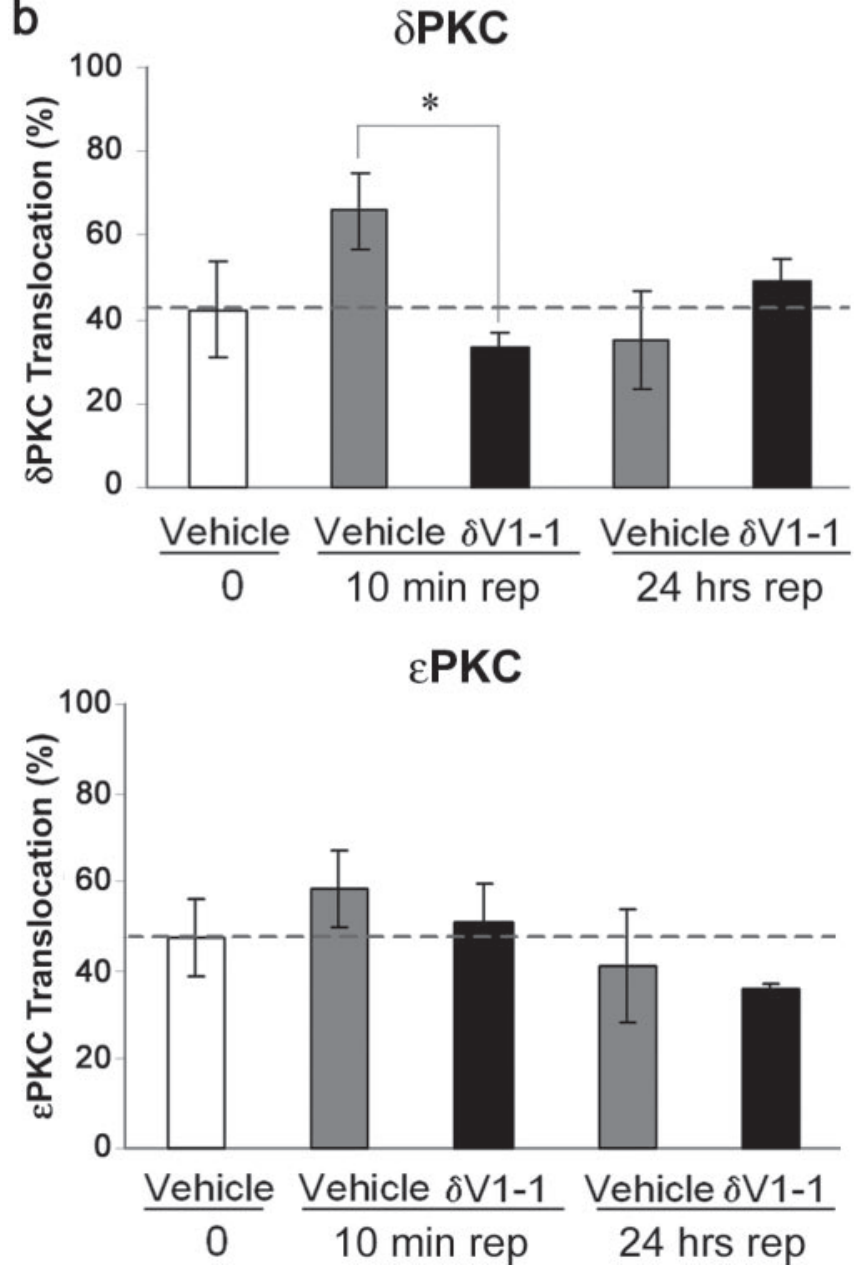

Figure 2. $\delta \mathrm{V} 1-1$ is delivered to the brain parenchyma in vivo after intra-arterial bolus. $a$, Background staining from sham brain (left) and corresponding staining of biotin-conjugated $\delta \mathrm{V} 1-1$ peptide in cortical neurons (right). $b$, Delivery of $\delta \mathrm{V} 1-1$ reduces $\delta$ PKC translocation after 10 min of reperfusion (rep) ( $n=3$ per group; ${ }^{*} p<0.05$ ). This effect was specific to $\delta P K C$; $\delta V 1-1$ had no effect on $\epsilon$ PKC translocation. Brain tissue was harvested from animals ( $\delta \mathrm{V} 1-1$ or Tat treated) after ischemia and $10 \mathrm{~min}$ or $24 \mathrm{hr}$ of reperfusion. Soluble and particulate fractions of brain tissue were subjected to Western blot analysis using anti- $\delta$ PKC (phospho-ser643 $\delta$ PKC) or anti- $\epsilon$ PKC antibodies.

focal ischemia model. Rats underwent $2 \mathrm{hr}$ MCAO, followed by either $10 \mathrm{~min}$ or $24 \mathrm{hr}$ of reperfusion. We found that $\delta \mathrm{PKC}$ was activated as measured by intracellular translocation after $10 \mathrm{~min}$ of reperfusion, and that this translocation was inhibited after in vivo delivery of $\delta \mathrm{V} 1-1$ at the onset of reperfusion (Fig. $2 b)(50 \%$ 
a

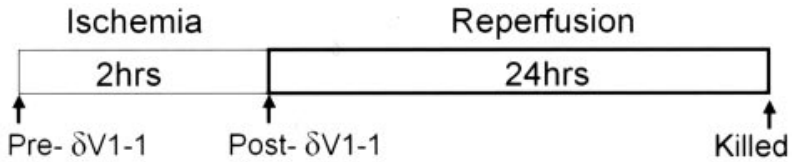

b
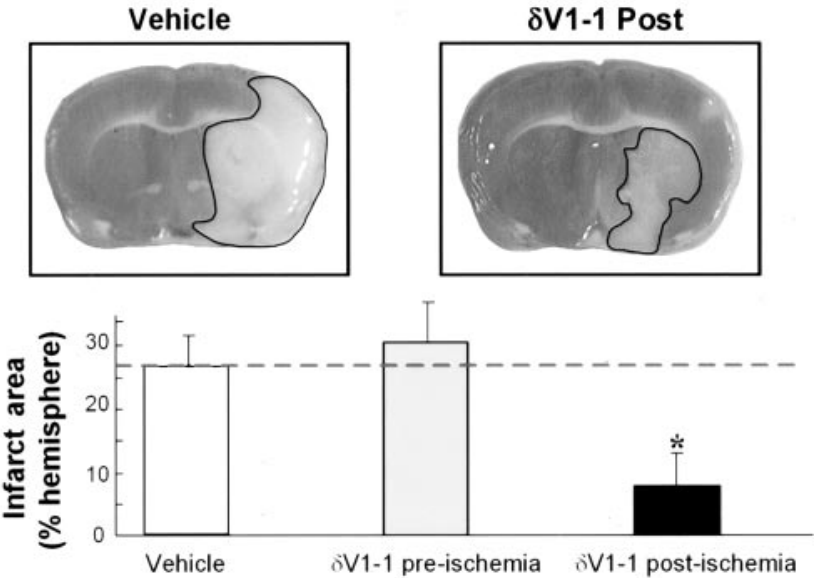

Figure 3. $\delta \mathrm{V} 1-1$ protects brain from reperfusion damage in vivo. $a$, Tat carrier peptide alone $(n=14)$ or $\delta V 1-1$ were delivered intra-arterially through the internal carotid artery immediately before ( $\delta \mathrm{V} 1-1$ preischemia; $n=8)$ or immediately after $(\delta \mathrm{V} 1-1$ postischemia; $n=10)$ a $2 \mathrm{hr}$ occlusion of the MCA. Animals were killed after $24 \mathrm{hr}$ of reperfusion, and brain slices were stained with TTC, which stains viable tissues red. Infarcted tissue appears white (marked with black border). $b$, Typical pictures from vehicle- and $\delta V 1-1$-treated animals $24 \mathrm{hr}$ after MCA occlusion. c, Delivery of $\delta \mathrm{V} 1-1$ after ischemia, but not before ischemia, reduced extent of brain infarction as measured after $24 \mathrm{hr}$ of reperfusion. Significance was compared with control $\left({ }^{*} p<0.05\right)$.

inhibition; $p<0.05)$. However, at $24 \mathrm{hr}$ of reperfusion, there was no difference in the $\delta \mathrm{PKC}$ translocation between the groups. Importantly, the effect of $\delta \mathrm{V} 1-1$ was selective (e.g., $\epsilon$ PKC translocation was not altered by the $\delta \mathrm{V} 1-1$ treatment) (Fig. $2 b$ ).

\section{$\delta \mathrm{V} 1-1$ reduced infarct size after in vivo delivery}

We next determined whether inhibition of $\delta \mathrm{PKC}$ translocation affected cerebral ischemic and reperfusion injury in vivo using a 2 hr transient MCA occlusion model of stroke, followed by a $24 \mathrm{hr}$ reperfusion period. Either $\delta \mathrm{V} 1-1$ or Tat (each at $250 \mathrm{~nm}$ final blood concentration) was delivered as a bolus dose via the internal carotid artery either immediately before the ischemic period (pre- $\delta \mathrm{V} 1-1)$ or at the onset of reperfusion (post- $\delta \mathrm{V} 1-1)$ (Fig. $3 a$ ). Delivery of the peptide did not alter standard physiological variables including blood $\mathrm{pH}$, glucose, blood gases $\left(\mathrm{pCO}_{2}, \mathrm{pO}_{2}\right)$, hematocrit, or mean arterial blood pressure. Brains were harvested after $24 \mathrm{hr}$ of reperfusion, and stroke area was assessed after staining with TTC. Treatment with the $\delta \mathrm{V} 1-1$ peptide prior to the ischemic event (pre- $\delta \mathrm{V} 1-1$ ) did not confer protection from subsequent ischemia and reperfusion injury $(30 \pm 7 \% ; n=$ $8)$. However, infarct areas were reduced by $68 \%$ in animals that were treated with $\delta \mathrm{V} 1-1$ at the onset of reperfusion (post- $\delta \mathrm{V} 1-1$; $8 \pm 4 \% ; n=10$ ) relative to Tat control-treated animals (vehicle; $26 \pm 5 \% ; n=14 ; p<0.05)$ (Fig. 3b,c).

\section{Delayed delivery of $\delta \mathrm{V} 1-1-$ Tat during reperfusion confers protection}

To determine whether $\delta \mathrm{PKC}$ activity was involved in nonacute events during reperfusion and to further define the therapeutic window for $\delta \mathrm{V} 1-1$ administration, we next determined whether $\delta$ V1-1 provided a protective effect when delivered at delayed time points during reperfusion (Fig. 4a). We found that a single
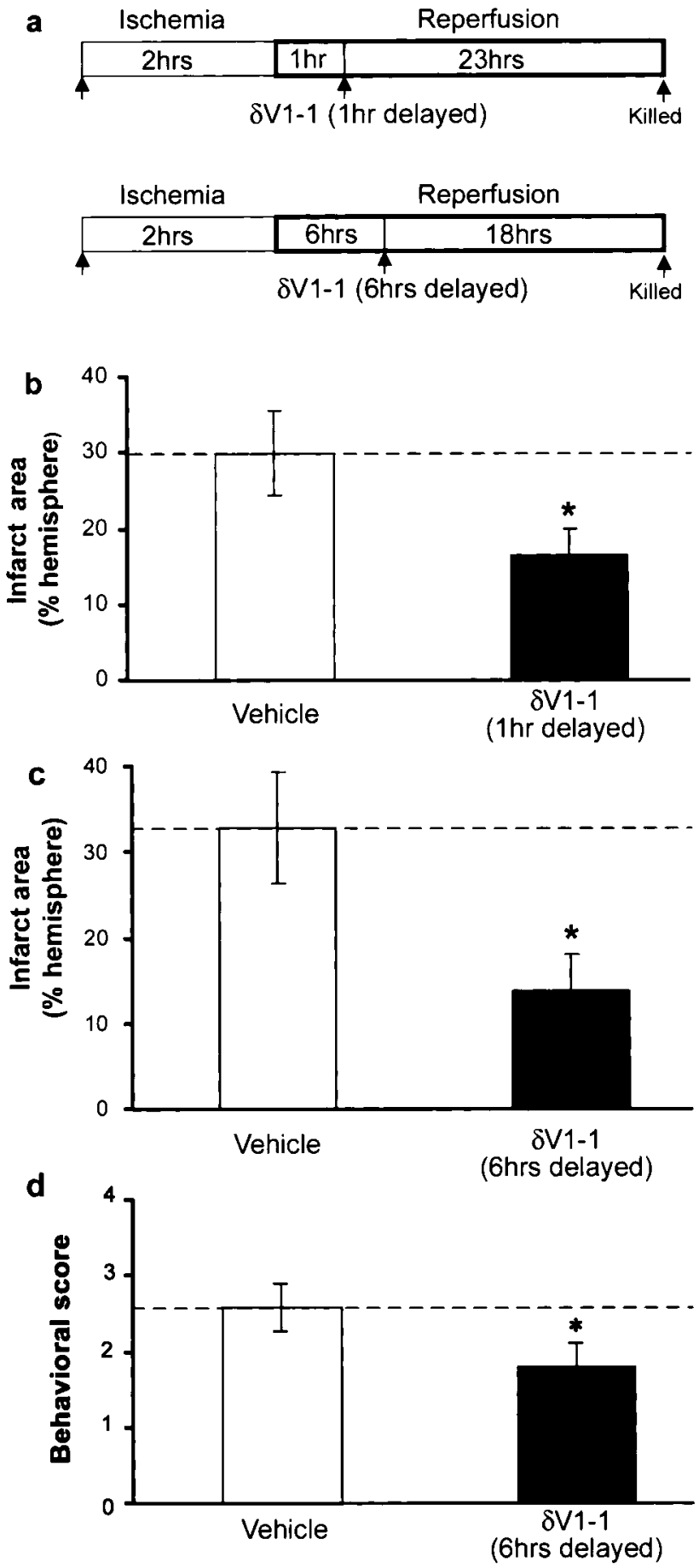

Figure 4. Delayed $\delta V 1-1$ delivery during reperfusion reduces infarct size in MCA0 model. $a$, Tat peptide alone or $\delta \mathrm{V} 1-1$ were delivered by intraperitoneal injection at 1 or $6 \mathrm{hr}$ after the onset of reperfusion. Animals were assessed for behavior $23 \mathrm{hr}$ later, killed, and brain infarct size was assessed using TTC. $b, \delta V 1-1$ delivery $1 \mathrm{hr}$ after the onset of reperfusion significantly reduced infarct size compared with Tat alone (vehicle, $n=11 ; \delta V 1-11 \mathrm{hr}, n=13 ;{ }^{*} p<0.05$ ). $c, \delta \mathrm{V} 1-1$ delivery $6 \mathrm{hr}$ after the onset of reperfusion significantly reduced infarct size compared with Tat peptide (vehicle, $n=9 ; \delta \mathrm{V} 1-16 \mathrm{hr}, n=9 ;{ }^{*} p<0.05$ ). $d, \delta \mathrm{V} 1-1$ peptide delivery 6 $\mathrm{hr}$ after the onset of reperfusion significantly decreases neurological deficit compared with animals treated with control peptide alone, as assessed at $24 \mathrm{hr}$ of reperfusion $\left({ }^{*} p<0.05\right)$.

intraperitoneal dose of $\delta \mathrm{V} 1-1$ peptide ( $20 \mathrm{nmol}$ bolus dose) at 1 $\mathrm{hr}$ after the onset of reperfusion also reduced infarct size compared with control ( $16 \pm 3$ vs $30 \pm 5 \%$, respectively; $p<0.05$ ) (Fig. $4 b$ ). In addition, we found that $\delta \mathrm{V} 1-1$ delivery $6 \mathrm{hr}$ after the 
onset of reperfusion (20 nmol) significantly reduced infarct size verses controls (14 vs 33\%, respectively; $p<0.05$ ) (Fig. $4 c$ ).

As a component of our MCAO animal protocol, we used the inhalational anesthetic isoflurane for induction and maintenance of anesthesia during the ischemic period alone. We recognize that isoflurane, like other anesthetics, has been shown previously to confer protection from cerebral ischemia-reperfusion injury when delivered before ischemia (Kapinya et al., 2002; Sullivan et al., 2002). However, isoflurane was used for anesthesia in both control-treated and $\delta \mathrm{V} 1-1$-treated animals during the ischemic period. Moreover, we found that $\delta \mathrm{V} 1-1$ conferred neuroprotection without the use of isoflurane in the hippocampal slice model of ischemia-reperfusion and has been shown previously to confer cardioprotection in models of cardiac ischemia-reperfusion injury without the use of isoflurane (Chen et al., 2001). Finally, $\delta \mathrm{V} 1-1$ was administered during a period independent of isoflurane delivery ( 1 and $6 \mathrm{hr}$ reperfusion) to confer protection and was administered during a period of isoflurane delivery (before ischemic onset) without conferring protection.

\section{$\delta \mathrm{V} 1-1$ reduces neurological deficit in animals after MCAO injury}

To determine whether delivery of $\delta \mathrm{V} 1-1$ lessens neurological deficit after MCAO injury, we selected one treatment group ( $\delta \mathrm{V} 1-1$ or control peptide delivered at $6 \mathrm{hr}$ postreperfusion) for behavioral assessment using a scale modified from the study by Yang et al. (1994). Animals were graded on a scale of 1-4, ranking increasing deficit as described above. Using this scoring system, we found that animals treated with $\delta \mathrm{V} 1-1$ peptide exhibited a significantly decreased behavioral score than control-treated animals, as assessed at $24 \mathrm{hr}$ reperfusion ( $1.8 \pm 0.3$ vs $2.6 \pm 0.3 ; p<$ 0.05 ) (Fig. $4 d$ ). Preserved neurological function in $\delta$ V $1-1$-treated animals corresponded to a $57 \%$ decrease in weight loss compared with controls after this $24 \mathrm{hr}$ period $(p<0.05)$, suggesting that $\delta \mathrm{V} 1-1$-treated animals may be feeding better, which is another indication of improved neurological function.

\section{$\delta$ V1-1 peptide reduces number of apoptotic cells after ischemic-reperfusion injury in vivo}

We next assessed whether $\delta \mathrm{V} 1-1$ affected the number of apoptotic cells in the in vivo model of ischemia-reperfusion injury. The number of TUNEL-positive cells was markedly diminished in slices treated with $\delta \mathrm{V} 1-1$ peptide (Fig. $1 e c$ ). In the in vivo model, brains were isolated after $2 \mathrm{hr}$ MCAO and $72 \mathrm{hr}$ of reperfusion. TUNEL-positive apoptotic cells were found primarily in the periinfarct region of the ipsilateral cortex (Fig. 5aa). However, in $\delta \mathrm{V} 1-1$-treated animals, apoptotic cell count was diminished (Fig. $5 a b)$. TUNEL-positive cells in four defined regions of the ipsilateral cortex were counted in $\delta \mathrm{V} 1-1$ - or control-treated animals. We found a reduction of $47 \%$ in $\delta \mathrm{V} 1-1$-treated animals compared with control-treated animals (Fig. $5 b$ ).

\section{$\delta$ V1-1 treatment alters phospho-Akt levels and BAD protein levels in the in vivo ischemia model}

To further determine the mechanism by which $\delta \mathrm{V} 1-1$ reduces cellular damage during reperfusion, we studied two markers for cell survival signaling and proapoptotic signaling, namely, activated Akt and the Bcl-2 family member BAD. Akt, the prosurvival enzyme, is active when phosphorylated on ser-473 and thr-308 (Alessi et al., 1996; Delcommenne et al., 1998). We found that there was a significant increase in phospho-Akt levels with respect to total Akt, when $\delta \mathrm{V} 1-1$ is delivered either at the onset of reperfusion $(64 \pm 3 \% ; p<0.05)$ or at $1 \mathrm{hr}$ into reperfusion $(54 \pm$
$9 \%)$ verses control animals $(38 \pm 4 \%)$. When $\delta \mathrm{V} 1-1$ was delivered $6 \mathrm{hr}$ after reperfusion, phospho-Akt was not significantly higher than control levels (Fig. $5 c, d$ ).

$\mathrm{BAD}$ protein becomes proapoptotic when it translocates from the cytosol to the mitochondria, where it associates with other members of the BCl-2 family of proteins (von Harsdorf et al., 1999). We found higher cytosolic levels of BAD with respect to total BAD protein in $\delta \mathrm{V} 1-1$-treated animals when treated at the onset of reperfusion $(53 \pm 10 \%$; $p<0.05)$ and $6 \mathrm{hr}$ into reperfusion $(48 \pm 1 \% ; p<0.05)$ compared with controls (35 $\pm 5 \%$ ). When $\delta \mathrm{V} 1-1$ was delivered at $1 \mathrm{hr}$ after ischemia, we observed increased cytosolic BAD; however, values did not reach statistical significance $(46 \pm 4 \%$ ) (Fig. $5 c, e$ ).

\section{Discussion}

In this study, we demonstrated that inhibition of $\delta \mathrm{PKC}$, using a $\delta$ PKC-selective inhibitor peptide, significantly reduced cerebral tissue damage when administered at the onset of reperfusion. This neuroprotection was achieved using two models of ischemic and reperfusion injury: an in vitro hippocampal slice culture model and an in vivo transient focal ischemia model.

\section{SV1-1 peptide delivery in vivo}

$\delta \mathrm{PKC}$ exists in a dynamic state, rapidly cycling between an inactive and an active state, when it is conformationally able to bind to its isozyme-specific anchoring molecule $\delta$ RACK (receptor for activated $\mathrm{C}$ kinase) and phosphorylate physiological substrates (Mochly-Rosen, 1995). The $\delta$ V1-1 peptide was rationally designed to block binding of activated $\delta \mathrm{PKC}$ to $\delta \mathrm{RACK}$ and thereby inhibit its activity. For passage through the blood-brain barrier and intracellular delivery, the $\delta \mathrm{V} 1-1$ peptide was conjugated to the cell membrane-permeating Tat-carrier peptide, which was previously shown to deliver peptides (Aarts et al., 2002) and proteins (Asoh et al., 2002; Cao et al., 2002; Kilic et al., 2002) to the brain parenchyma in vivo.

We demonstrated that $\delta \mathrm{PKC}$ translocation was significantly reduced in the brain after both in vitro and in vivo delivery of $\delta \mathrm{V} 1-1$, consistent with access of the peptide to the brain parenchyma. In addition, the remarkably parallel protective effects of $\delta \mathrm{V} 1-1$ between the in vivo MCAO model and the in vitro hippocampal slice model, in which blood-brain barrier transport of the peptide is not a factor, suggest similar access and activity of the peptide to cells at risk in both models. Importantly, we also found that delivery of the peptide by an intra-arterial bolus or by intraperitoneal delivery greatly reduced infarct size, suggesting that peripheral routes of delivery are effective in administration of this peptide therapeutic to the CNS.

\section{$\delta \mathrm{V} 1-1$ reduces damage from reperfusion injury}

There is little consensus on whether individual PKC isozymes play a damaging or beneficial role in cellular injury after stroke. Here, we demonstrated that rapid activation of $\delta \mathrm{PKC}$ occurred in compromised tissue at the onset of reperfusion after MCA occlusion. Within $10 \mathrm{~min}$ of reperfusion after a $2 \mathrm{hr}$ stroke, $\delta \mathrm{PKC}$ was activated, as shown by its translocation from the soluble to the membrane fraction. This rapid translocation suggests a role for $\delta \mathrm{PKC}$ in mediating reperfusion damage after ischemia and indicates an opportunity for intervention by selective inhibition of this enzyme.

The timing of $\delta \mathrm{V} 1-1$ delivery further supports our hypothesis that $\delta \mathrm{PKC}$ activity mediates reperfusion injury processes. We found that delivery of $\delta \mathrm{V} 1-1$ during the OGD period alone in the hippocampal slice model or before ischemia in the MCAO model 
a
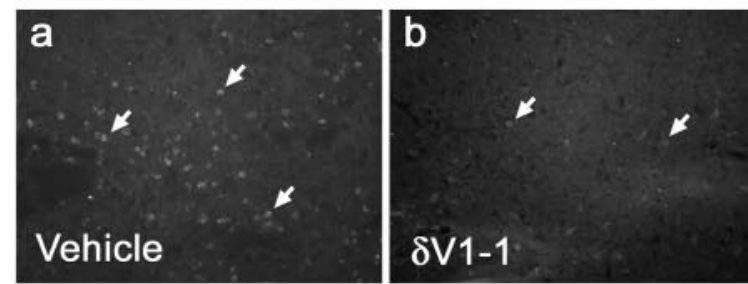

b

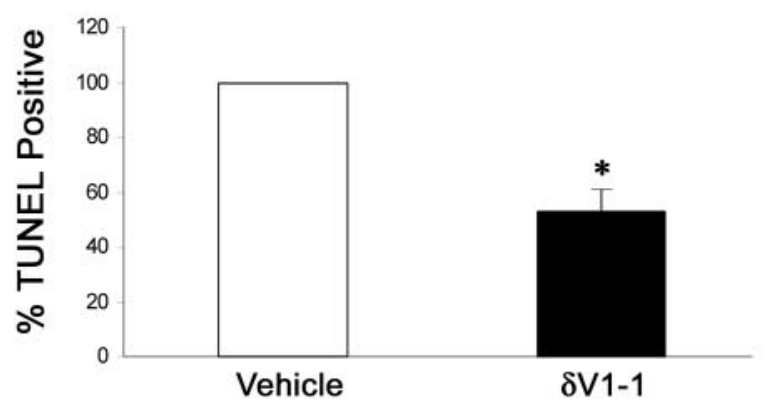

C

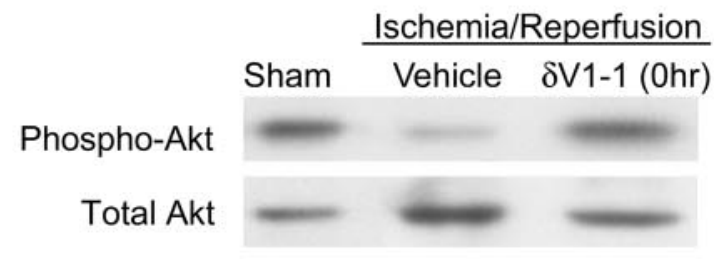

\begin{tabular}{|c|c|}
\hline \multicolumn{2}{|c|}{ Ischemia/Reperfusion } \\
\hline Vehicle & $\delta \mathrm{V} 1-1$ (Ohr) \\
\hline $\mathrm{s}$ & $\mathrm{S}$ \\
\hline
\end{tabular}

BAD

$\beta$-Actin

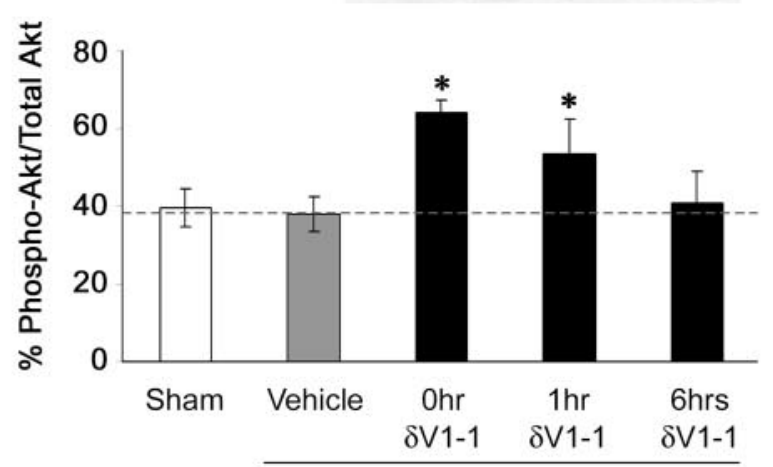

e

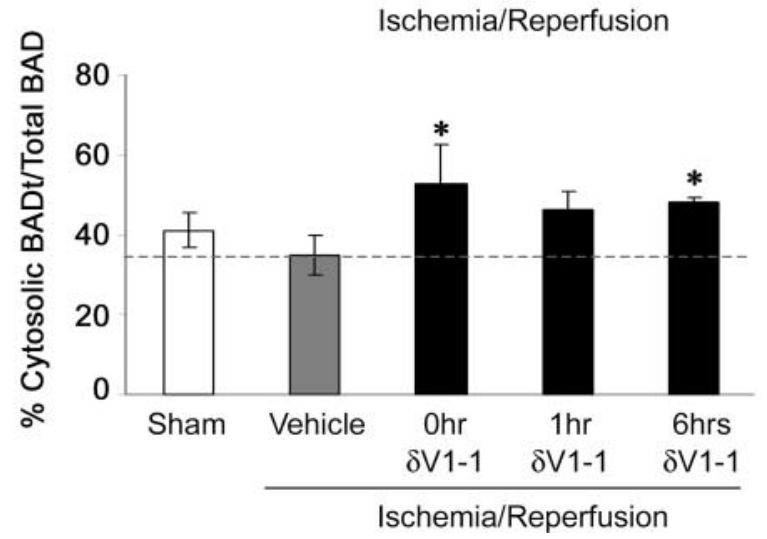

provided no observable protection from cerebral injury. In contrast, delivery of $\delta \mathrm{V} 1-1$ during the reperfusion period significantly protected the brain. In the in vitro slice model, delivery during OGD and the first $3 \mathrm{hr}$ of reperfusion decreased neuronal death. Similarly, in the in vivo model, delivery of $\delta \mathrm{V} 1-1$ at the onset of reperfusion, $1 \mathrm{hr}$, or $6 \mathrm{hr}$ into reperfusion significantly reduced infarct size and corresponded with improved neurological outcome. We therefore suggest that $\delta$ PKC-induced neuronal damage may occur for several hours during reperfusion. The protective effect of this peptide at $6 \mathrm{hr}$ after the onset of reperfusion also suggests its potential clinical value for late reperfusion injury (Jonas et al., 2001).

\section{$\delta \mathrm{PKC}$ in intracellular injury processes}

Reperfusion injury is a major cause of cerebral damage after transient ischemia (Yang and Betz, 1994). The process of reperfusion is known to produce characteristic changes, including excitotoxic damage, inflammation, edema, and apoptosis (for review, see Lipton, 1999). Apoptosis involves a highly regulated system of cell death pathways and has been observed in multiple tissues in response to ischemic-reperfusion injury (Schumer et al., 1992; Gottlieb et al., 1994; Li et al., 1995). A growing body of literature suggests that $\delta \mathrm{PKC}$ plays a central role in mediating apoptosis (Gutcher et al., 2003). In a model of cardiac ischemia and reperfusion, we recently demonstrated a detrimental role for $\delta \mathrm{PKC}$, promoting mitochondrial damage and induction of apoptosis (Inagaki et al., 2003b). Recent studies demonstrate that inhibition of $\zeta \mathrm{PKC}$, but not $\delta \mathrm{PKC}$, confers protection to neuron-astrocyte cultures exposed to a level of NMDA, which produced excitotoxic cell death (Koponen et al., 2003). The absence of protection conferred by the $\delta \mathrm{PKC}$ inhibitor may be attributable to the lack of apoptotic cell death in this model. These findings, together with our evidence that $\delta \mathrm{PKC}$ inhibitor peptide exhibited a CNS-protective effect when delivered during reperfusion, suggest that $\delta \mathrm{V} 1-1$ may confer protection, at least in part, by inhibiting proapoptotic processes. We therefore investigated whether $\delta$ PKC alters markers for apoptotic cell change and cell survival.

We demonstrated that in both in vitro and in vivo models of cerebral ischemic-reperfusion injury, there was a significant reduction in the number of TUNEL-positive cells in $\delta \mathrm{V} 1-1$-treated slices (CA1 region) or animals (ipsilateral cortex), compared with control-peptide treatments. Interestingly, this reduction in apoptotic cell death was observed at $3 \mathrm{~d}$ postischemia in the MCAO

\footnotetext{
$\leftarrow$

Figure 5. $\quad \delta V 1-1$ peptide treatment reduces apoptosis and alters levels of prosurvival and apoptotic markers after cerebral ischemia. After $72 \mathrm{hr}$ of reperfusion, brains treated with either $\delta V 1-1$ or Tat peptide at the onset of reperfusion were harvested and stained using TUNEL (Tat, $n=3 ; \delta V 1-1, n=4) . a, b$, Images were taken of ipsilateral cortex $(100 \times)$ in control-treated $(a)$ and $\delta$ V1-1-treated $(b)$ animals. *Arrows indicate TUNEL-positive cells. $b$, TUNEL-positive cells were counted in four defined regions of the ipsilateral cortex in each slice. A 47\% decrease in TUNEL-positive cell count was seen in $\delta \mathrm{V} 1-1$-treated animals compared with control animals $\left({ }^{*} p<0.05\right)$. c, After $24 \mathrm{hr}$ of reperfusion, lysates from brains treated with Tat peptide alone (vehicle, $n=5)$ or $\delta$ V1-1 at the onset $(n=5)$, at $1 \mathrm{hr}(n=4)$, or at $6 \mathrm{hr}(n=4)$ of reperfusion or brains from sham-treated animals $(n=4)$ were subject to Western blot analysis for phosphorylated Akt and BAD. $\beta$-actin was used to confirm protein levels. $d$, Levels of phospho-Akt were markedly increased with respect to total Akt in animals treated with $\delta \mathrm{V} 1-1$ peptide versus vehicle-treated animals at the onset of reperfusion and at $1 \mathrm{hr}$ of reperfusion $\left({ }^{*} p<0.05\right)$. Levels were not significantly different from controls in animals treated with $\delta \mathrm{V} 1-1$ at $6 \mathrm{hr}$ into reperfusion. $e, \mathrm{BAD}$ protein translocation from the cytosol to the membrane bound fraction was inhibited in animals treated with $\delta V 1-1$ at the onset of reperfusion $\left({ }^{*} p<\right.$ 0.05 ) at $1 \mathrm{hr}$ (did not reach statistical significance) or at $6 \mathrm{hr}$ of reperfusion ( ${ }^{*} p<0.05$ ). Graph represents levels of cytosolic BAD protein with respect to total BAD protein.
} 
model and is a first indication that protection conferred by $\delta \mathrm{V} 1-1$ is sustained for several hours (Valtysson et al., 1994).

Based on these findings, we sought to determine more precisely the role of $\delta \mathrm{PKC}$ in mediating apoptotic injury. We therefore assessed alterations in markers for cell survival and apoptotic pathways after ischemia-reperfusion. Akt (protein kinase B) mediates survival responses to a number of cell-death stimuli, including DNA damage, cell-cycle misregulation, and more recently, ischemia (Downward, 1998; Noshita et al., 2001). Thus, maintenance of Akt activity is important to cell survival. Using the $2 \mathrm{hr}$ MCAO model, we found that cerebral ischemia-reperfusion injury caused a reduction in activated (phospho ser-473) Akt levels and that delivery of $\delta \mathrm{V} 1-1$ inhibited this reduction in active Akt. These data suggest that inhibition of $\delta \mathrm{PKC}$ in the first hour of reperfusion promoted cell-survival signals in the brain through preserving Akt activity. However, when $\delta \mathrm{V} 1-1$ was delivered after $6 \mathrm{hr}$ of reperfusion, levels of active Akt were similar to the control group. This suggests that the neuroprotective activity of $\delta \mathrm{V} 1-1$ is not mediated by Akt at this later time window and that $\delta \mathrm{PKC}$ may be involved in alternative, or even multiple, signaling pathways to mediate cell death, according to the phase of reperfusion damage and cellular state (for review, see Lipton, 1999). Alternatively, this data may imply that the observed increase in active Akt is secondary to $\delta \mathrm{V} 1-1$ conferred protection.

Interestingly, Akt has also been linked to apoptotic cell-death pathways by phosphorylation of the Bcl-2 family member BAD at ser-136 (Datta et al., 1997). When phosphorylated, BAD is sequestered in the cytoplasm. After an apoptotic stimulus, BAD is dephosphorylated and subsequently translocates to the mitochondria, contributing to mitochondrial dysfunction (Yang et al., 1995; Zha et al., 1996). We were unable to determine the levels of phosphorylated BAD. However, consistent with the expected change in BAD distribution, we observed a decrease in cytosolic $\mathrm{BAD}$ and correlated increase in membrane-bound $\mathrm{BAD}$ in the brain of animals subject to ischemia followed by $24 \mathrm{hr}$ of reperfusion. Importantly, in animals treated with $\delta \mathrm{V} 1-1$, the ratio of cytosolic- to membrane-bound BAD was increased. These data indicate that BAD translocation out of the cytoplasm, and thus its proapoptotic activity, was inhibited in animals treated with $\delta \mathrm{V} 1-1$. Together, these data suggest that inhibition of $\delta \mathrm{PKC}$ increased activity of the prosurvival enzyme Akt and inhibited the activity of the proapoptotic protein BAD. Although the signaling pathways between $\delta \mathrm{PKC}$ and downstream cell survival markers are only partly defined, the consistency of this observation in multiple models of ischemia and reperfusion support a role for $\delta$ PKC upstream of cell survival (Murriel and Mochly-Rosen, 2004).

Reperfusion also promotes secondary damage through unregulated neurotransmitter release, decrease in cellular energy stores, and inhibition of electron transport, leading to changes in cell permeability and free radical generation (for review, see Lipton, 1999). Previous work has outlined a role for PKC isozymes in these responses and suggests a correlation between sustained glutamate release, PKC activity, and downstream neuronal damage (Miettinen et al., 1996; Nakane et al., 1998; Skeberdis et al., 2001). These studies raise the possibility that other pathways may also be involved in $\delta \mathrm{PKC}$-mediated reperfusion damage and suggests additional avenues by which inhibition of $\delta$ PKC may confer neuroprotection. Alternatively, the protective effect of the $\delta \mathrm{V} 1-1$ peptide may occur in part through altering cerebral blood flow (CBF) after ischemia. However, as the peptide was protective in an in vitro model, where vascular function does not mediate out- come, we suggest the neuroprotective effect cannot be caused by its effect on CBF alone.

Our data indicate that $\delta \mathrm{PKC}$ mediates cerebral reperfusion damage and is the first report that inhibition of this enzyme greatly improves histopathologic and behavioral outcome after stroke in vivo. We suggest that multiple $\mathrm{PKC}$ isozymes play a role in cerebral ischemic-reperfusion injury with unique windows of activity during the ischemic and reperfusion periods. Here, we show a selective role for $\delta \mathrm{PKC}$ as a mediator of reperfusion damage but not ischemic injury. These data underscore the importance of using isozyme-selective tools to assess the role of individual $\mathrm{PKC}$ isozymes in mediating ischemic and reperfusion damage of the CNS and the therapeutic potential of a selective $\delta \mathrm{PKC}$ inhibitor on injury progression after cerebral ischemia and reperfusion.

\section{References}

Aarts M, Liu Y, Liu L, Besshoh S, Arundine M, Gurd JW, Wang YT, Salter MW, Tymianski M (2002) Treatment of ischemic brain damage by perturbing NMDA receptor-PSD-95 protein interactions. Science 298:846-850.

Alessi DR, Andjelkovic M, Caudwell B, Cron P, Morrice N, Cohen P, Hemmings BA (1996) Mechanism of activation of protein kinase B by insulin and IGF-1. EMBO J 15:6541-6551.

Asoh S, Ohsawa I, Mori T, Katsura K, Hiraide T, Katayama Y, Kimura M, Ozaki D, Yamagata K, Ohta S (2002) Protection against ischemic brain injury by protein therapeutics. Proc Natl Acad Sci USA 24:17107-17112.

Bergold PJ, Casaccia-Bonnefil P (1997) Preparation of organotypic hippocampal slice cultures using the membrane filter method. Methods Mol Biol 72:15-22.

Brodie C, Blumberg PM (2003) Regulation of cell apoptosis by protein kinase $C$ delta. Apoptosis 8:19-27.

Cao G, Pei W, Ge H, Liang Q, Luo Y, Sharp FR, Lu A, Ran R, Graham SH, Chen J (2002) In vivo delivery of Bcl-xL fusion protein containing TAT protein transduction domain protects against ischemic brain injury and neuronal apoptosis. J Neurosci 22:5423-5431.

Chao CC, Hu S, Peterson PK (1995) Modulation of human microglial cell superoxide production by cytokines. J Leukoc Biol 58:65-70.

Chan PH (2001) Reactive oxygen radicals in signaling and damage in the ischemic brain. J Cereb Blood Flow Metab 21:2-14.

Chen L, Hahn H, Wu G, Chen CH, Liron T, Schechtman D, Cavallaro G, Banci L, Guo Y, Bolli R, Dorn GW II, Mochly-Rosen D (2001) Opposing cardioprotective actions and parallel hypertrophic effects of delta PKC and epsilon PKC. Proc Natl Acad Sci USA 98:11114-11119.

Conti AC, Raghupathi R, Trojanowski JQ, McIntosh TK (1998) Experimental brain injury induces regionally distinct apoptosis during the acute and delayed post-traumatic period. J Neurosci 18:5663-5672.

Datta SR, Dudek H, Tao X, Masters S, Fu H, Gotoh Y, Greenberg ME (1997) Akt phosphorylation of BAD couples survival signals to cell-intrinsic death machinery. Cell 91:231-241.

Delcommenne M, Tan C, Gray V, Rue L, Woodgett J, Dedhar S (1998) Phosphoinositide-3-OH kinase-dependent regulation of glycogen synthase kinase 3 and protein kinase B/Akt by the integrin-linked kinase. Proc Natl Acad Sci USA 15:11211-11216.

Downey JM, Cohen MV, Ytrehus K, Liu Y (1994) Cellular mechanisms in ischemic preconditioning: the role of adenosine and protein kinase C. Ann NY Acad Sci 17:82-98.

Downward J (1998) Mechanisms and consequences of activation of Protein kinase B/Akt. Curr Opin Cell Biol 10:262-267.

Gottlieb RA, Burleson KO, Kloner RA, Babior BM, Engler RL (1994) Reperfusion injury induces apoptosis in rabbit cardiomyocytes. J Clin Invest 94:1621-1628.

Gutcher I, Webb PR, Anderson NG (2003) The isoform-specific regulation of apoptosis by protein kinase C. Cell Mol Life Sci 60:1061-1070.

Inagaki K, Chen L, Ikeno F, Lee FH, Imahashi K, Bouley DM, Rezaee M, Yock PG, Murphy E, Mochly-Rosen D (2003a) Inhibition of delta protein kinase $\mathrm{C}$ against reperfusion injury of the ischemic heart, in vivo. Circulation 108:2304-2307.

Inagaki K, Hahn HS, Dorn GW II, Mochly-Rosen D (2003b) Additive protection of the ischemic heart ex vivo by combined treatment with delta- 
protein kinase $\mathrm{C}$ inhibitor and epsilon-protein kinase $\mathrm{C}$ activator. Circulation 19:869-875.

Johnson JA, Mochly-Rosen D (1995) Inhibition of the spontaneous rate of contraction of neonatal cardiac myocytes by protein kinase $\mathrm{C}$ isozymes. A putative role for the epsilon isozyme. Circ Res 76:654-663.

Jonas S, Aiyagari V, Vieira D, Figueroa M (2001) The failure of neuronal protective agents versus the success of thrombolysis in the treatment of ischemic stroke Ann NY Acad Sci 939:257-267.

Kapinya KJ, Lowl D, Futterer C, Maurer M, Waschke KF, Isaev NK, Dirnagl U (2002) Tolerance against ischemic neuronal injury can be induced by volatile anesthetics and is inducible NO synthase dependent. Stroke 33:1889-1898.

Kilic E, Dietz GP, Hermann DM, Bahr M (2002) Intravenous TAT-Bcl-Xl is protective after middle cerebral artery occlusion in mice. Ann Neurol $52: 617-622$.

Koponen S, Goldsteins G, Keinanen R, Koistinaho J (2000) Induction of protein kinase $\mathrm{C}$ delta subspecies in neurons and microglia after transient global brain ischemia. J Cereb Blood Flow Metab 20:93-102.

Koponen S, Kurkinen K, Akerman KEO, Mochly-Rosen D, Chan PH, Koistinaho J (2003) Prevention of NMDA-induced death of cortical neurons by inhibition of protein kinase C zeta. J Neurochem 86:442-450.

Kraft AS, Anderson WB (1983) Phorbol esters increase the amount of $\mathrm{Ca}^{2+}$, phospholipid-dependent protein kinase associated with plasma membrane. Nature 301:621-623.

Li Y, Sharov VG, Jiang N, Zaloga C, Sabbah HN, Chopp M (1995) Ultrastructural and light microscopic evidence of apoptosis after middle cerebral artery occlusion in the rat. Am J Pathol 146:1045-1051.

Lipton P (1999) Ischemic cell death in brain neurons. Physiol Rev 79:1431-1568.

Maier CM, Sun GH, Kunis D, Yenari MA, Steinberg GK (2001) Delayed induction and long-term effects of mild hypothermia in a focal model of transient cerebral ischemia: neurological outcome and infarct size. J Neurosurg 94:90-96.

Miettinen S, Roivainen R, Keinanen R, Hokfelt T, Koistinaho J (1996) Specific induction of protein kinase $\mathrm{C}$ delta subspecies after transient middle cerebral artery occlusion in the rat brain: inhibition by MK-801. J Neurosci 16:6236-6245.

Mochly-Rosen D (1995) Localization of protein kinases by anchoring proteins: a theme in signal transduction. Science 268:247-251.

Murriel CL, Mochly-Rosen D (2004) Opposing roles of delta and epsilon $\mathrm{PKC}$ in cardiac ischemia and reperfusion; targeting the apoptotic machinery. Arch Biochem Biophys 420:246-254.

Nakane H, Yao H, Ibayashi S, Kitazono T, Ooboshi H, Uchimura H, Fujishima M (1998) Protein kinase C modulates ischemia-induced amino acids release in the striatum of hypertensive rats. Brain Res 26:290-296.

National Institute of Neurological Disorders and Stroke (1995) Tissue plasminogen activator for acute ischemic stroke. The National Institute of Neurological Disorders and Stroke rt-PA stroke study group. N Engl J Med 333:1581-1587.

Noshita N, Lewen A, Sugawara T, Chan PH (2001) Evidence of phosphorylation of Akt and neuronal survival after transient focal cerebral ischemia in mice. J Cereb Blood Flow Metab 21:1442-1450.

Padanilam BJ (2001) Induction and subcellular localization of protein kinase C isozymes following renal ischemia. Kidney Int 59:1789-1797.
Phan TG, Wright PM, Markus R, Howells DW, Davis SM, Donnan GA (2002) Salvaging the ischaemic penumbra: more than just reperfusion? Clin Exp Pharmacol Physiol 29:1-10.

Pringle AK, Iannotti F, Wilde GJ, Chad JE, Seeley PJ, Sundstrom LE (1997) Neuroprotection by both NMDA and non-NMDA receptor antagonists in in vitro ischemia. Brain Res 25:36-46.

Raval AP, Dave KR, Mochly-Rosen D, Sick TJ, Perez-Pinzon MA (2003) Epsilon PKC is required for the induction of tolerance by ischemic and NMDA-mediated preconditioning in the organotypic hippocampal slice. J Neurosci 23:384-391.

Schumer M, Colombel MC, Sawczuk IS, Gobe G, Connor J, O’Toole KM, Olsson CA, Wise GJ, Buttyan R (1992) Morphologic, biochemical, and molecular evidence of apoptosis during the reperfusion phase after brief periods of renal ischemia. Am J Pathol 140:831-838.

Schwarze SR, Ho A, Vocero-Akbani A, Dowdy SF (1999) In vivo protein transduction: delivery of a biologically active protein into the mouse. Science 285:1569-1572.

Selvatici R, Marino S, Piubello C, Rodi D, Beani L, Gandini E, Siniscalchi A (2003) Protein kinase C activity, translocation, and selective isoform subcellular redistribution in the rat cerebral cortex after in vitro ischemia. J Neurosci Res 71:64-71.

Sieber FE, Traystman RJ, Brown PR, Martin LJ (1998) Protein kinase C expression and activity after global incomplete cerebral ischemia in dogs. Stroke 29:1445-1452.

Skeberdis VA, Lan J, Opitz T, Zheng X, Bennett MV, Zukin RS (2001) mGluR1-mediated potentiation of NMDA receptors involves a rise in intracellular calcium and activation of protein kinase C. Neuropharmacology 40:856-865.

Sullivan BL, Leu D, Taylor DM, Fahlman CS, Bickler PE (2002) Isoflurane prevents delayed cell death in an organotypic slice culture model of cerebral ischemia. Anesthesiology 96:189-195.

Valtysson J, Hillered L, Andine P, Hagberg H, Persson L (1994) Neuropathological endpoints in experimental stroke pharmacotherapy: the importance of both early and late evaluation. Acta Neurochir 129:58-63.

von Harsdorf R, Li PF, Dietz R (1999) Signaling pathways in reactive oxygen species-induced cardiomyocyte apoptosis. Circulation 99:2934-2941.

Wieloch T, Cardell M, Bingren H, Zivin J, Saitoh T (1991) Changes in the activity of protein kinase $\mathrm{C}$ and the differential subcellular redistribution of its isozymes in the rat striatum during and following transient forebrain ischemia. J Neurochem 56:1227-1235.

Yang G-Y, Betz AL (1994) Reperfusion-induced injury to the blood-brain barrier after middle cerebral artery occlusion in rats. Stroke 25:1658-1664.

Yang G, Chan PH, Chen J, Carlson E, Chen SF, Weinstein P, Epstein CJ, Kamii H (1994) Human copper-zinc superoxide dismutase transgenic mice are highly resistant to reperfusion injury after focal cerebral ischemia. Stroke 25:165-170.

Yang E, Zha J, Jockel J, Boise LH, Thompson CB, Korsmeyer SJ (1995) Bad, a heterodimeric partner for $\mathrm{Bcl}-\mathrm{XL}$ and $\mathrm{Bcl}-2$, displaces $\mathrm{Bax}$ and promotes cell death. Cell 80:285-291.

Zha J, Harada H, Yang E, Jockel J, Korsmeyer SJ (1996) Serine phosphorylation of death agonist BAD in response to survival factor results in binding to 14-3-3 not BCL-X(L). Cell 87:619-628. 